\title{
Microstructure Analysis of Hydroxyapatite Coating on Stainless Steel 316L Using Investment Casting Technique for Implant Application
}

\author{
Nuzul Ficky Nuswantoro ${ }^{1}$, Gunawarman ${ }^{2 *}$, Masagus Rifqie Saputra ${ }^{2}$, Is Prima Nanda ${ }^{2}$, Mohd. Hasbullah \\ Idris $^{3}$, Andril Arafat ${ }^{3}$ \\ ${ }^{1}$ Biomedical Science Department, Faculty of Medicine, Andalas University, Padang, 25121, Indonesia \\ E-mail:nuswantoro.ratissa@gmail.com \\ ${ }^{2}$ Mechanical Engineering Department, Engineering Faculty, Andalas University, Padang, 25163, Indonesia \\ E-mail: ${ }^{*}$ gunawarman@ft.unand.ac.id
}

${ }^{3}$ Department of Materials, Manufacturing \& Industrial Engineering, Faculty of Mechanical Engineering, Universiti Teknologi Malaysia, 81310 Skudai, Johor, Malaysia

\begin{abstract}
Osteoporosis and traffic accidents are a significant factor that causes a bone fracture in Indonesia. One solution for the bones fracture treatment is by using fixation implant that has similar characteristics with the human bones. Stainless Steel (SS) 316L is one of biomaterial that has been used as an implant material due to its corrosion resistance, excellent biocompatibility, and excellent mechanical properties. However, the bioactivity properties of the material are needed to improve by coating it with hydroxyapatite (HA). In this research, HA was coated to the surface of 316 LS by using investment casting technique. A slurry of HA was poured into the casting cavity surface prior to the metal casting process and then followed by sintering at temperatures of $850^{\circ} \mathrm{C}, 9^{\circ} 0^{\circ} \mathrm{C}$, and $950^{\circ} \mathrm{C}$. Characterization of $\mathrm{HA}$ coating layer on specimen surface was conducted by Optical Microscope, Scanning Electron Microscope (SEM), and Energy Dispersive X-Ray (EDX). The hardness of the samples was measured by Vickers Hardness Tester. The result of the experiment shows that the investment casting is successfully to coat the HA on the SS 316L surface. Pouring method produces HA layer with thickness (spongy and porous surface) in the range of $60 \mu \mathrm{m}-110 \mu \mathrm{m}$. The increasing of sintering temperature increases the hardness number of the surfaces, and affect the purity of HA, but it is not related to coating thickness. The optimum sintering temperature is obtained at $900^{\circ} \mathrm{C}$ which produces the best calcium and phosphate ratio. The investment casting method is found as a simple and non-expensive technique that can be used to coat HA powder to SS 316L that produces good properties and optimum crystallinity of HA that suitable for orthopaedic implant application.
\end{abstract}

Keywords - coating; stainless steel 316L; hydroxyapatite; investment casting.

\section{INTRODUCTION}

Bone fracture cases tend to increase in Indonesia in which osteoporosis and traffic accidents are significant factors that cause the bone fracture. Global Status Report on Road Safety by the World Health Organization explains that about $78 \%$ of a traffic accident in Indonesia is due to the bones fracture [1,2]. Indonesia Ministry of Health reported, in 2011 there is around 100.000 cases of osteoporosis and predicted to increase 3 times in 2050[3]. Bone fracture treatment in orthopaedic is usually conducted by metal implant fixation for bone reposition and immobilization to support bone remodelling [4].

Material that used to make orthopaedic implant is called as a biomaterial. Over the last 30 years, considerable progress has been made in understanding the interactions between the tissues and implant materials. The material that is used as an implant should have similar characteristics with living tissue that being replace and has excellent biocompatibility [5]. Mechanical and biological properties of implant need to be optimal to form a quick and excellent connection with the surrounding biological environment in the human body [6].

Every kind of implant material has their own different application depend on the part of the body that will be replaced [7]. The metal implant is chosen due to their superior mechanical properties and their biocompatibility [7,8]. Metal such as SS 316L and titanium become the most significant number of metal that used as an implant material due to its stability [9]. However, cost comparison made SS 
$316 \mathrm{~L}$ is more affordable than titanium. The excellence mechanical properties of stainless steel such as high strength and toughness, high corrosion resistance, biocompatibility and non-toxicity made this metal used as an implant for any application, such as fracture fixation, stents, and surgical instruments [4,11]. However, the application of the coating on the implant with bioactive materials must be conducted to improve their fixation in the human body [12].

$\mathrm{HA}$ or $\mathrm{Ca}_{10}\left(\mathrm{PO}_{4}\right)_{6}(\mathrm{OH})_{2}$ shows the most significant potential for bone substitution. This material can develop strong bonding with bone tissue, exhibit osteoconductivity, and stable toward bioresorption, and has no adverse effects on the human body [13]. HA is one of the ceramics materials which has bioactive properties and has a similar characteristic and composition with bones and teeth. In addition, HA can increase the corrosion resistance of SS $316 \mathrm{~L}$, accelerate the healing of bones and teeth, and also increase the shear strength of the implant $[14,15]$. However, HA is brittle and relatively weak material in its acceptable form and cannot be used as a structural bone replacement. Consequently, HA is usually applied as a coating on sturdy implantable metal materials in order to benefit from the mechanical strength of material together with the excellent biological properties of HA[16,17].

There are many kinds of coating methods that can be used to coat SS $316 \mathrm{~L}$ with HA including plasma spray, electro disposition, electrochemical disposition, sol-gel, pulsed laser disposition, and investment casting[6,18]. Investment casting is one of the casting methods which produces close tolerance metal with an inexpensive cost as compared to other coating methods. This method is easy to control and can maintain consistency of HA coating thickness in application to small and complex shapes. Another method that uses an investment casting to coat HA into SS $316 \mathrm{~L}$ is pouring method. This method is similar to dipping method, but the differences are that HA slurry in the pattern is mixed while the pouring method the HA slurry is poured into the mould before it coated with SS 316L[12,19]. Investment casting method is also can be used to apply the coating in cobalt alloy material with wollastonite in order to gain bioactivity properties of implant materials [20]. This research will use the pouring method to coat HA slurry to SS $316 \mathrm{~L}$ followed by a sintering process. This coating method is still not used yet as a commercial process to produce an implant. So, it is necessary more research for this method before it is commercially implemented.

\section{MATERIAL AND METHOD}

\section{A. Sample Preparation}

The HA powder that used was the commercial HA powder provided by coating laboratory Department of Materials, Manufacturing \& Industrial Engineering, Faculty of Mechanical Engineering, Universiti Teknologi Malaysia, with specification is shown in Table 1.

Casting preparation was started on wax pattern preparation. The shape of the wax was made similar to the final product. HA was coated into the mould cavity as a mixture of HA powder and addition of a binder. The binder was made with the addition of distillate water with Colloidal Silica at Viscosity of 5 (Zahn Cup no.5). The ceramic mould was made in multilayer. Preparation of mould started by the preparation of mould slurry. Ceramic shell mould was made in six layers. After that, the mould was dried in 5 hours. Then, dewaxing was conducted to free all of the wax from the mould. After that, the mould was sintered. HA was coated on the surface of the mould. HA was coated by pouring method with Colloidal Silica as the binder.

TABLE I

HA POWDER PROPERTIES

\begin{tabular}{|l|l|}
\hline \multicolumn{2}{|c|}{ HYDROXYAPATITE PROPERTIES } \\
\hline Material Name & Hydroxyapatite Powder \\
\hline Particle Size & $62.1 \mu \mathrm{m}$ \\
\hline Producers & Whitecross Road Industrial Estate \\
\hline Country Producer & United Kingdom \\
\hline
\end{tabular}

SS $316 \mathrm{~L}$ was melted by the furnace at $1500^{\circ} \mathrm{C}$. The melting process was conducted with an argon gas environment. Then, molten SS 316L was poured into the mould and let it until become hard. After that, the specimen was cut by sawing machine. Sintering process was conducted at a temperature of $850^{\circ} \mathrm{C}, 900^{\circ} \mathrm{C}$ and $950^{\circ} \mathrm{C}$. Sintering process was aimed to produce better properties of the material.

\section{B. Specimen Characterization}

Characterization of the specimen was conducted by Scanning Electron Microscope (SEM) to observe the surface morphology and surface coverage of HA coating. Energy Dispersive X-Ray (EDX) was used to analyze the chemical composition of the specimen. Vickers Hardness Tester was used to measure the hardness of the specimen. Hardness was gained from a micro-hardness number of the specimen.

\section{RESULT AND DISCUSSION}

\section{A. HA Coating on The Mould}

Fig. 1 shows the optical micrograph of the cross-sectional area of the mould. HA coating on mould surface has variation in thickness. Fig. 1(a) shows that HA cover all part of the mould surface. The HA layer is spongy and porous with porosity average is about $150 \mu \mathrm{m}$. Fig. 1(b) shows the thickness of HA on the cross-sectional area of the mould. The thickness of coatings is $651 \mu \mathrm{m}, 941 \mu \mathrm{m}, 1029 \mu \mathrm{m}$, and $915 \mu \mathrm{m}$, respectively for number 1 to 4 in Fig. 1(b). Coating thickness from another cross-sectional area in specimens is shown in Table 2.

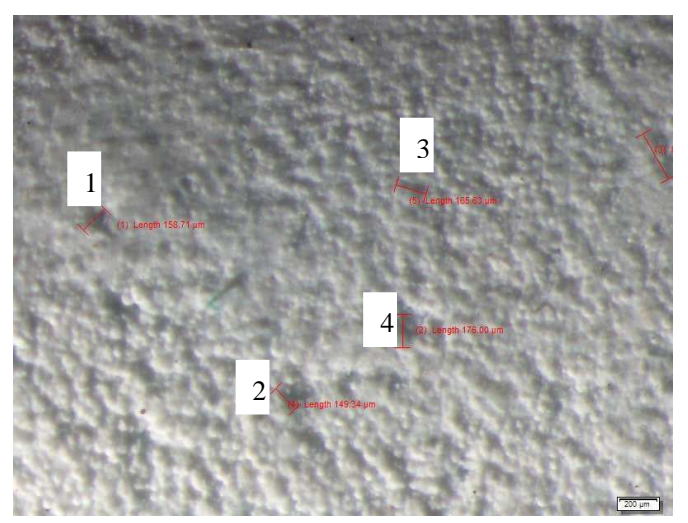

(a) 


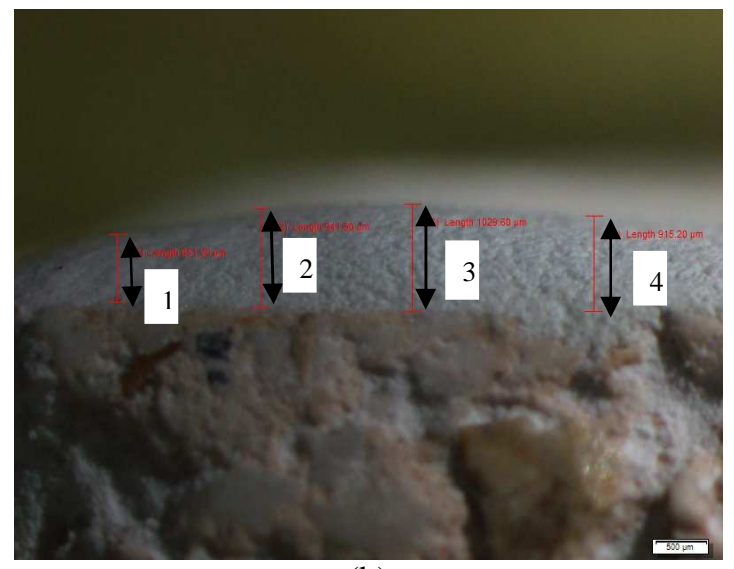

(b)

Fig. 1 (a) HA coating on mould surfaces and (b) Thickness of HA coating observed on the first Cross-Sectional Area of the Specimen.

The highest thickness that measured from the crosssectional area is $1100 \mu \mathrm{m}$. The average thickness is about $933 \mu \mathrm{m}$. In this current study, HA coating has a wide variation in thickness. But, the other study that using the dipping method produce a uniform layer of HA on the inside of the mould. In this current study, HA coating thickness is thicker than another study through the same method[19]. Another study about HA coating on a cobalt base alloy by investment casting also revealed that a thicker coating is formed on a sample cast into the investment mould without heat treatment. Based on the result we can assume that the different thickness of HA coating on the mould is affected by the uneven heating process[21]. However, the HA coating thickness and surface coverage show good characteristics and the mould suitable to cast with SS $316 \mathrm{~L}$.

In addition, the other essential characteristics that must be considered is the calcium and phosphate ratio of HA. Based on SEM and EDX assessment, HA coating that produced in this current study is suitable for orthopaedic implant application. It has the optimum calcium and phosphate ratio of HA powder to gained good properties for implant materials, that are between 1.67 - 1.76 (Table 3.) [22]. Another study also revealed that increasing of mould preheated temperature from $750^{\circ} \mathrm{C}$ to $1050^{\circ} \mathrm{C}$ in investment casting process can produce more optimum calcium/phosphate ratio [23]. Table 3 shows HA characteristics. The different compound between the spectrums made different calcium and phosphate ratio on the mould. Calcium and phosphate ratio that obtained is about 1.68 on average. Based on the result, a mould that produced in this current study has excellent characteristics and suitable to cast with SS 316L [22].

\section{B. Surface Morphology of SS 316L with HA Coating}

Fig. 2 shows an optical image of SS 316L surface with HA coating. Based on this picture, HA coating layer that is produced has black colour; this might be caused by high temperature of molten SS 316L that directly contacted with HA slurry on the mould surface. However, there is no literature that discusses the correlation between physical appearance (colour) and the implant performance. HA coating layer that produces is porous and spongy; this might be caused by a casting process that is not perfect.
TABLE II

THE THICKNESS OF HA COATING ON THE MOULD.

\begin{tabular}{|c|c|c|}
\hline $\begin{array}{c}\text { Indicated Cross } \\
\text { Sectional Area }\end{array}$ & Indicated Points & Thickness $(\boldsymbol{\mu m})$ \\
\hline \multirow{3}{*}{1} & 1 & 651 \\
\cline { 2 - 3 } & 2 & 941 \\
\cline { 2 - 3 } & 3 & 1029 \\
\cline { 2 - 3 } & 4 & 915 \\
\hline \multirow{3}{*}{2} & 1 & 803 \\
\cline { 2 - 3 } & 2 & 1100 \\
\cline { 2 - 3 } & 3 & 957 \\
\hline \multirow{3}{*}{3} & 4 & 840 \\
\cline { 2 - 3 } & 1 & 1001 \\
\cline { 2 - 3 } & 2 & 950 \\
\cline { 2 - 3 } & 3 & 1020 \\
\hline \multirow{2}{*}{ Average } & 995 \\
\hline \multicolumn{2}{|c|}{} & 933.5 \\
\hline
\end{tabular}

TABLE III

THE COMPOSITION OF HA ON MOULD

\begin{tabular}{|c|c|c|c|c|}
\hline \multirow{2}{*}{ Spectrums } & \multicolumn{4}{|c|}{ \% Weight } \\
\cline { 2 - 5 } & $\mathbf{C a}$ & $\mathbf{P}$ & $\mathbf{S i}$ & $\mathbf{C a} / \mathbf{P}$ \\
\hline 1 & 30.7 & 18.3 & 6.8 & 1.67 \\
\hline 2 & 26.8 & 15.7 & 6.8 & 1.7 \\
\hline 3 & 30.1 & 18 & 6.1 & 1.67 \\
\hline Average & 29.2 & 17.3 & 6.56 & 1.68 \\
\hline
\end{tabular}

Specimen with higher sintering temperature shows better surface morphology than the others. Specimen with sintering temperature at $950^{\circ} \mathrm{C}$ gained $\mathrm{HA}$ coating with high surface coverage, spongy, and crack-free layer. Based on the result, it can be assumed that increasing sintering temperature would make higher surface coverage of HA coating on the stainless steel surface.

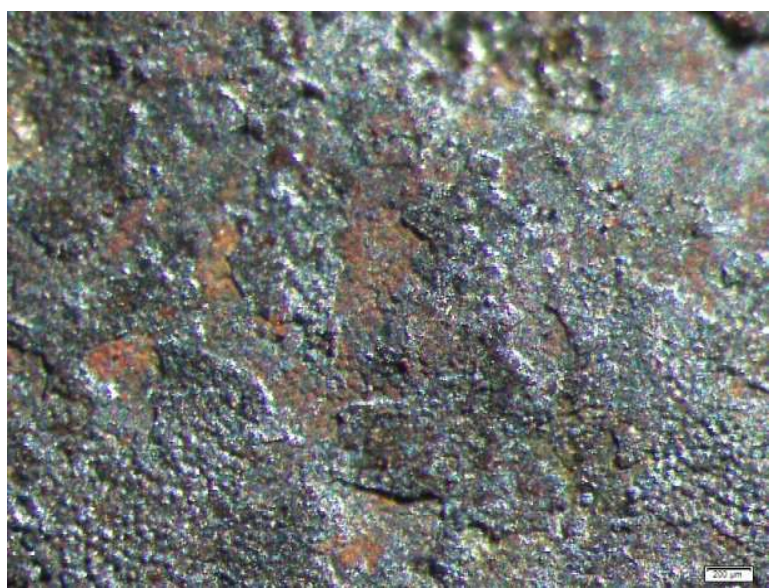

(a) 


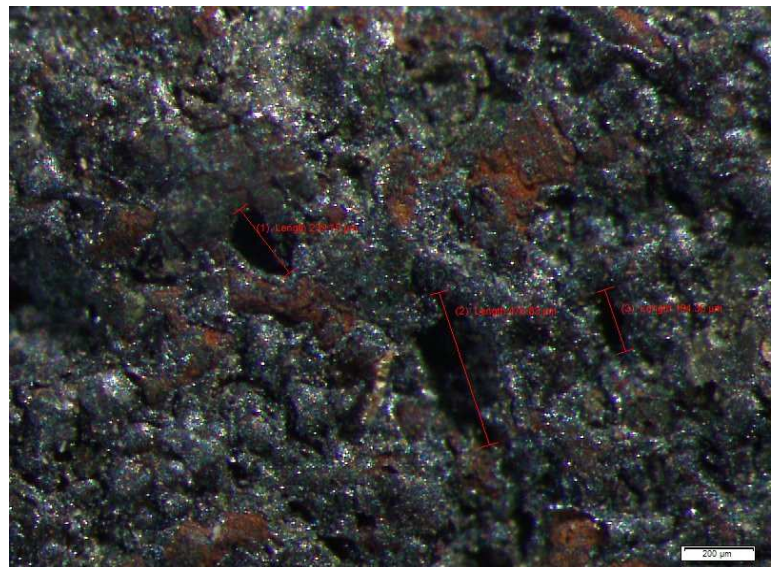

(b)

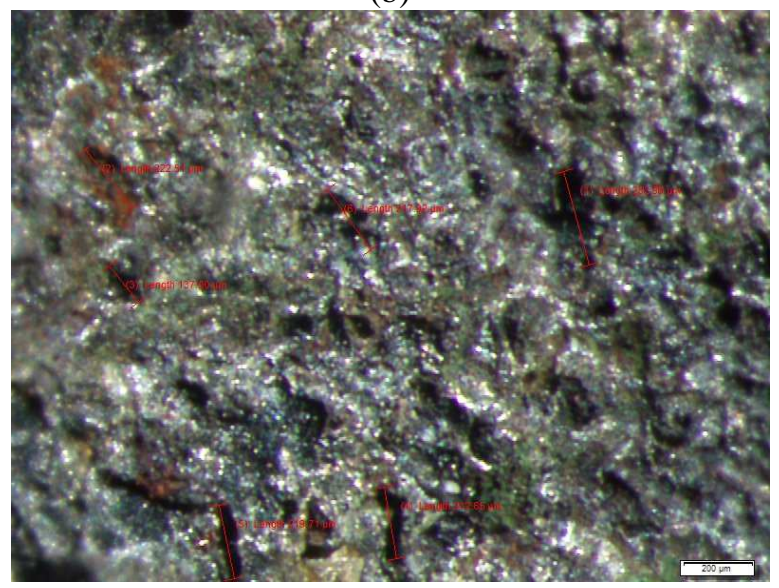

(c)

Fig. 2 Surface morphology of HA coating on materials with sintering temperature at (a) $850^{\circ} \mathrm{C}$ (b) $900^{\circ} \mathrm{C}$ (c) $950^{\circ} \mathrm{C}$

\section{Chemical Composition of HA Coating}

Fig. 3 shows the composition spectrum of the specimen. This result is appropriate with the result from an optical image of the specimen surface. The result shows in Fig. 3 and Table 4.

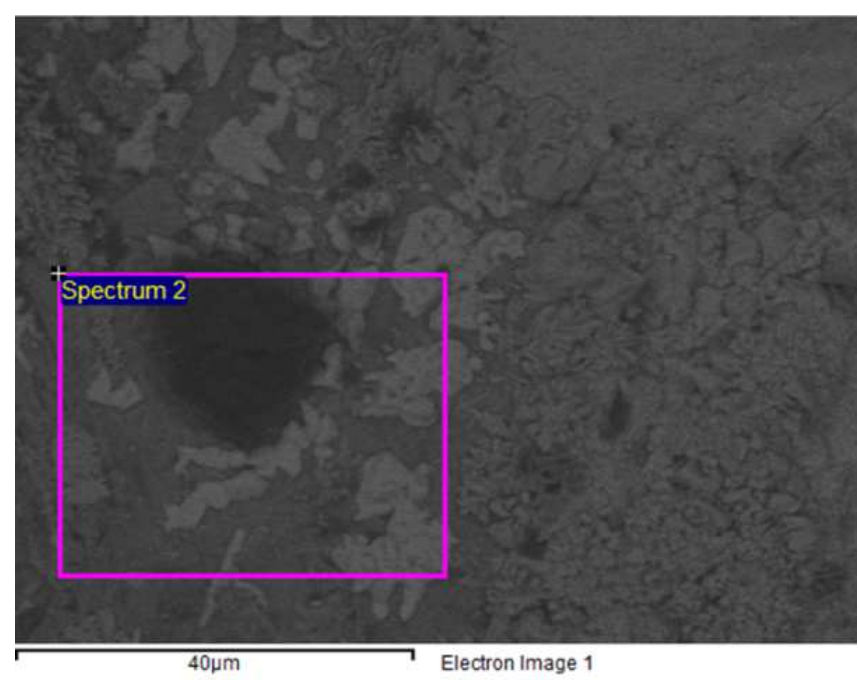

(a)

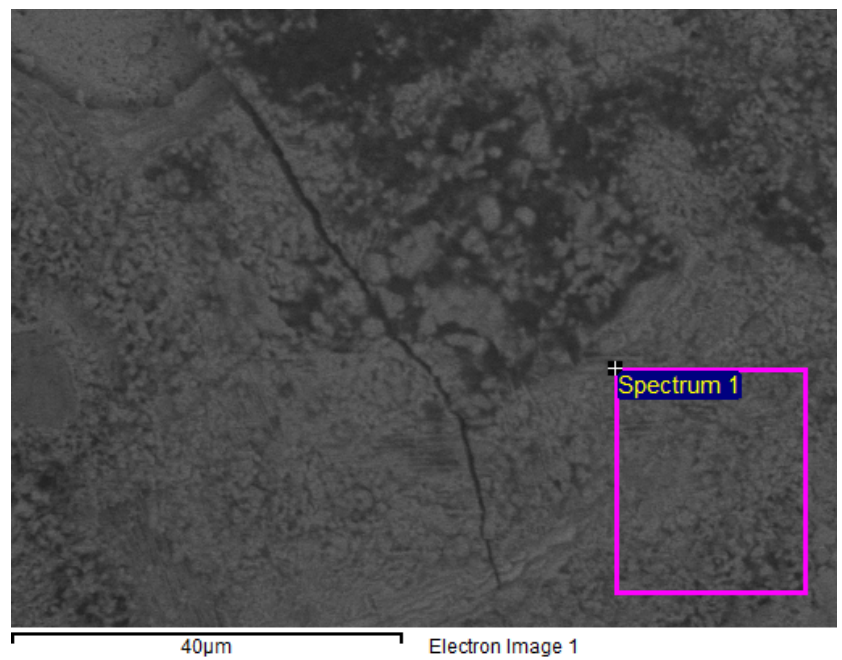

(b)

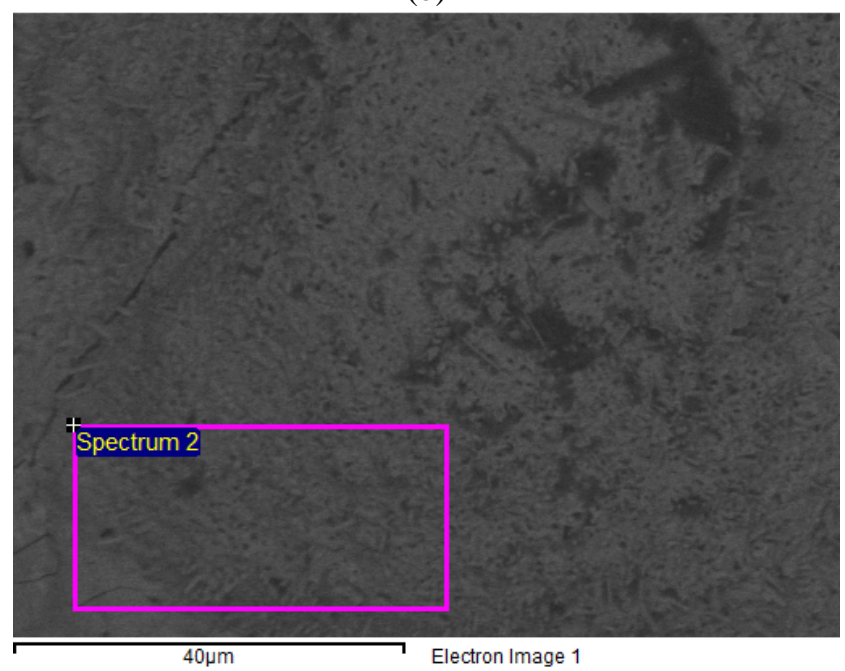

(c)

Fig. 3 The spectrum composition from the specimen with sintering temperature at (a) $850{ }^{\circ} \mathrm{C}$, (b) $900^{\circ} \mathrm{C}$, (c) $950{ }^{\circ} \mathrm{C}$.

TABLE IV

The Composition OF SPeCimen SS 316L AFter Sintering Process

\begin{tabular}{|c|c|c|c|c|}
\hline \multirow{2}{*}{$\begin{array}{l}\text { Speciment } \\
\left({ }^{\circ} \mathrm{C}\right)\end{array}$} & \multirow{2}{*}{ Spectrums } & \multicolumn{3}{|c|}{ \% Weight } \\
\hline & & $\mathbf{C a}$ & $\mathbf{P}$ & $\mathrm{Ca} / \mathrm{P}$ \\
\hline \multirow{3}{*}{$850{ }^{\circ} \mathrm{C}$} & 1 & 9.28 & 5.39 & 1.72 \\
\hline & 2 & 10.28 & 6.01 & 1.71 \\
\hline & 3 & 6.38 & 3.77 & 1.69 \\
\hline \multirow{3}{*}{$900{ }^{\circ} \mathrm{C}$} & 1 & 3.48 & 2.07 & 1.68 \\
\hline & 2 & 2.91 & 1.74 & 1.67 \\
\hline & 3 & 2.98 & 1.77 & 1.681 \\
\hline \multirow{3}{*}{$950{ }^{\circ} \mathrm{C}$} & 1 & 2.79 & 1.55 & 1.8 \\
\hline & 2 & 6.33 & 3.47 & 1.82 \\
\hline & 3 & 3.08 & 1.7 & 1.81 \\
\hline \multicolumn{2}{|c|}{ Average } & 5.27 & 3.05 & 1.72 \\
\hline
\end{tabular}

Phosphate and calcium are the two materials that build the structure of bones. HA has a similar characteristic with a bone mineral that contains calcium and phosphate. According to orchid orthopaedics, the purity (ratio of calcium and phosphate) of the HA in implant material must be between $1.67-1.76$ [22]. Based on composition test conducted by EDX (Table 4.) there is an uncontrol distribution composition of the calcium and phosphate on the 
specimens. For $850^{\circ} \mathrm{C}$ specimen, the range of calcium presentation on the specimen in the range of $6.38 \%$ $10.28 \%$, the phosphate is between $3.77 \%-6.01 \%$ from the overall composition of the material in spectrums. For $900^{\circ} \mathrm{C}$ specimen, there is a close-range percentage of the composition. The percent range between $2.91 \%-3.48 \%$ in calcium and $1.77 \%$ - $2.07 \%$ in phosphate. For $950^{\circ} \mathrm{C}$ specimen percent of calcium is between $2.79 \%-6.33 \%$ and phosphate is between $1.55 \%-3.47 \%$.

The high number of calcium and phosphate on the $850^{\circ} \mathrm{C}$ specimen in the second spectrum is caused by the porosity effect from the casting process. The porosity made the hoarding of calcium and phosphate, but the ratio is kept in the range of $1.67 \%-1.76 \%$. Based on the result, it is proved that $850{ }^{\circ} \mathrm{C}-900{ }^{\circ} \mathrm{C}$ is the optimum temperature. On the other hand, the best sintering temperature is observed at the $900{ }^{\circ} \mathrm{C}$. Another study also revealed that increasing of hydroxyapatite crystallinity is effected by increasing of sintering temperature. Calcium/phosphate ratio that obtained from other study are 1.69 and 1.61 with a sintering temperature of about 800 and $1000^{\circ} \mathrm{C}[19]$. This result means that investment casting is a potential technology that can be used to produce an orthopaedic implant with HA coating which has excellent properties and optimum crystallinity of HA appropriate with orthopaedic implant application.

\section{Coating Thickness}

Coating thickness is observed at the cross-sectional area of the specimen and analyzed by SEM. The result is shown in Table 5. Based on the result, the specimen with sintering temperature at $950{ }^{\circ} \mathrm{C}$ and $900{ }^{\circ} \mathrm{C}$ have $61 \mu \mathrm{m}$ coating thickness. The specimen with a sintering temperature of 850 ${ }^{\circ} \mathrm{C}$ has an increasing thickness average about $71 \mu \mathrm{m}$. Another study explained the optimum thickness of the HA coating is less than $100 \mu \mathrm{m}$ to gain an optimum characteristic that appropriate to orthopaedic implant application [22]. In this research, the coating thickness that produced is in the range of $60 \mu \mathrm{m}-73 \mu \mathrm{m}$ and suitable for implant application. The increase of sintering temperature is not related to the change of the HA thickness due to the sintering process is aimed to enhance the bonding between HA particle on the implant surface. Fig. 4 shows that HA coating thickness on the specimen has a different value (random distribution point). The averaged thickness is $65 \mu \mathrm{m}$.

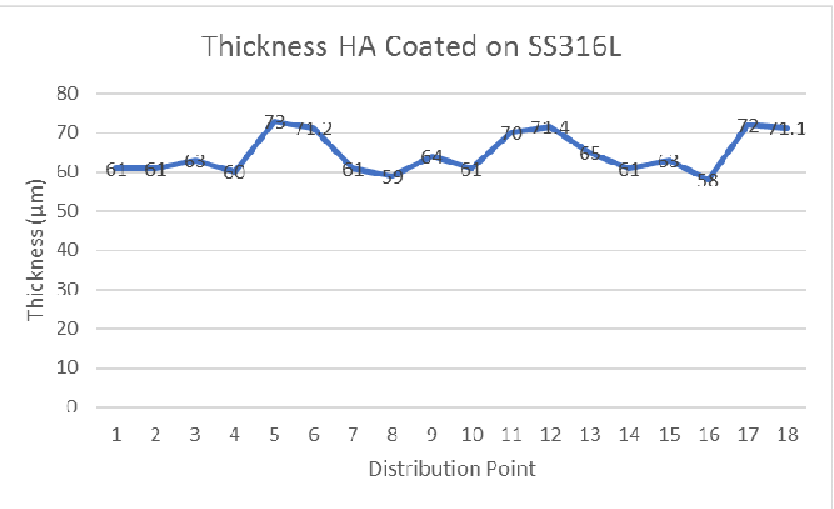

Fig. 4 The thickness of HA-coated on SS316L with the Random distribution point.
The coating thickness of HA on the implant surface is also a significant factor that affects the ability of orthopaedic implants. A study that is also evaluating the characteristic of hydroxyapatite coating on implant material revealed that the increase of coating thickness could increase corrosion resistant of the implant material and also increase the shear strength of the implant surface. The recommended coating thickness is under $100 \mu \mathrm{m}$ that could stimulate optimum bone growth and osseointegration $[14,15]$.

TABLE V

THE THICKNESS OF HA COATING ON SS 316L

\begin{tabular}{|c|c|c|c|c|c|}
\hline \multirow{2}{*}{$\begin{array}{c}\text { Specimen } \\
\text { Number }\end{array}$} & $\begin{array}{c}\text { Temperature } \\
\left({ }^{\circ} \mathbf{C}\right)\end{array}$ & \multicolumn{2}{|c|}{ Thickness $(\boldsymbol{\mu m})$} & \multirow{2}{*}{$\begin{array}{c}\text { Thickness } \\
\text { Average }\end{array}$} \\
\cline { 2 - 5 } & $\mathrm{HT} 950^{\circ} \mathrm{C}$ & 61 & 61 & 65 & 62 \\
\hline \multirow{2}{*}{1} & $\mathrm{HT} 950^{\circ} \mathrm{C}$ & 61 & 59 & 61 & 60 \\
\cline { 2 - 5 } & $\mathrm{HT} 900^{\circ} \mathrm{C}$ & 63 & 64 & 63 & 63 \\
\hline \multirow{2}{*}{3} & $\mathrm{HT} 900^{\circ} \mathrm{C}$ & 60 & 61 & 58 & 59 \\
\hline \multirow{2}{*}{3} & $\mathrm{HT} 850^{\circ} \mathrm{C}$ & 73 & 70 & 72 & 71 \\
\cline { 2 - 4 } & $\mathrm{HT} 850^{\circ} \mathrm{C}$ & 71.2 & 71.4 & 71.1 & 71 \\
\hline
\end{tabular}

Another method is conducted to measure the hydroxyapatite coating thickness with coating thickness measurement equipment. This equipment is called coating thickness gauges. This tools used to measure the coating thickness on the specimen and the result shown in Table 6 compared with the thickness that observed by cross-sectional area.

TABLE VI

Thickness MEASUREd By COATING THICKNESS GAUGES

\begin{tabular}{|c|c|c|c|}
\hline \multirow{2}{*}{ Temperature / Point } & \multicolumn{3}{|c|}{ Thickness $(\boldsymbol{\mu m})$} \\
\cline { 2 - 4 } & HT $950{ }^{\circ} \mathrm{C}$ & HT $900{ }^{\circ} \mathrm{C}$ & HT $850{ }^{\circ} \mathrm{C}$ \\
\hline 1 & 100 & 100 & 102 \\
\hline 2 & 98 & 96 & 108 \\
\hline 3 & 101 & 98 & 104 \\
\hline Average & 99 & 98 & 104 \\
\hline
\end{tabular}

Table 6 shows that the average thickness that obtained is about $100 \mu \mathrm{m}$. This result is different with the result by the cross-sectional area that observed by SEM. The different result that obtained from SEM and coating thickness gauges might be caused by the ashes on the surface of the material that also measured. On the other hand, the different result in the cross-sectional area method might be caused by HA collapse. Thickness comparison between cross-sectional area and coating thickness gauges shown in Table 7.

TABLE VII

THE COMPARISON BETWEEN THE THICKNESS RESULT OF DIFFERENT COATING METHOD [21]

\begin{tabular}{|l|l|}
\hline Coating Technique & Coating Thickness $(\boldsymbol{\mu m})$ \\
\hline Plasma Spraying & $50-250$ \\
\hline Biomimetic Deposition & $>30$ \\
\hline RF Magnetron Sputtering & $0.5-5$ \\
\hline Electrospray Deposition & $0.1-5$ \\
\hline Pulsed Laser Deposition & $0.005-5$ \\
\hline Ball Mill & $0.95-2.25$ \\
\hline Electrophoretic Deposition & $14-49$ \\
\hline Investment Casting & $60-110$ \\
\hline
\end{tabular}


HA coating by the investment casting process produces a thick layer of HA. Because of that, it is needed to find another method that can produce an optimum thickness of the HA coating. Another method that can be recommended is the dipping method. The investment casting method that conducted in this research produces a rough surface on the implanted specimen. It might be caused by an unperfect casting process. For the recommendation, the casting process must be conducted in the vacuum condition.

\section{E. Hardness Number}

The hardness number of the specimen observed by Vickers Hardness Tester to obtain the micro-hardness number of HA-coated on the SS 316L. Fig. 5 shows the effects of sintering temperature on the micro-hardness result of HA coating on SS 316L.

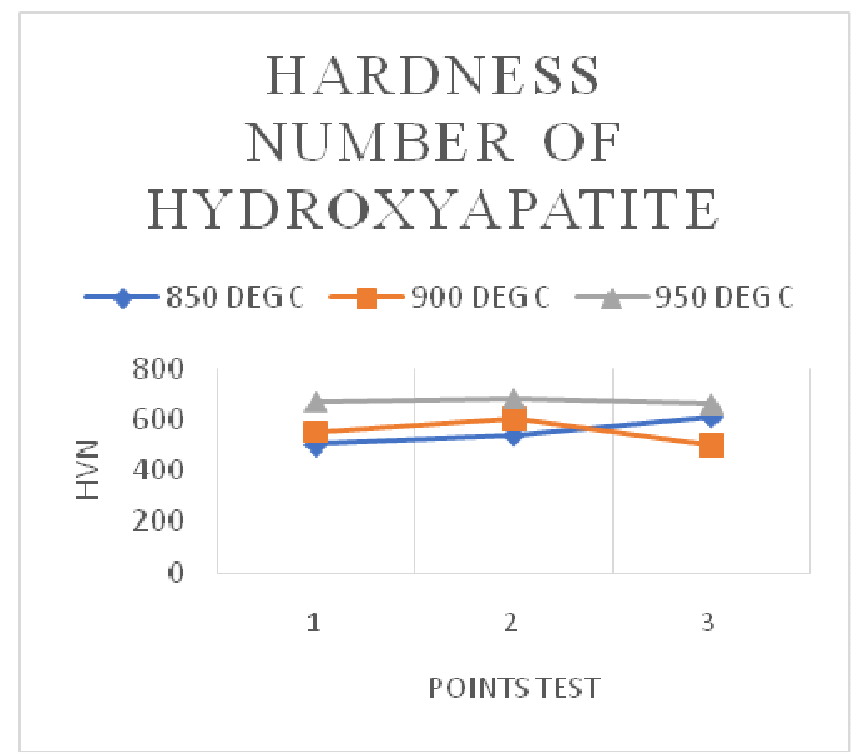

Fig. 5 Microhardness of HA-coated on Stainless Steel 316L

Heat treatment of the HA coating on the specimen started from the contact with the molten SS $316 \mathrm{~L}$ and finished with the normalizing of the HA. After that, the process is continued with the sintering process to make better properties of HA and finished by the annealing process. Fig. 5 shows that the micro-hardness number of the specimen is about $500-683 \mathrm{HVN}$. The micro-hardness number of apatite is started from $659 \mathrm{HVN}$ [16]. However, in this research, the average hardness number of HA coating is 592 HVN. It can be assumed that the heat treatment from the casting and sintering process made the HA smoother, but for $950^{\circ} \mathrm{C}$ the micro-hardness remains the same.

Fig. 5 shows that it can be assumed that the different sintering temperature produced the different hardness number of HA. Increasing sintering temperature produces smoother HA coating. On the other hand, increasing sintering temperature will increase Hardness Vickers Number. The increasing hardness number would increase the toughness of the implant and made the implant material more durable [25]. It can be assumed that $950^{\circ} \mathrm{C}$ is the suitable sintering temperature to produce better HA coating properties on implant materials.

On the other hand, another study revealed that the bioactivity of HA could decrease in implant material that is treated with heat treatment. Decreasing of HA bioactivity is caused by decomposition HA on the implant as the effect of heat treatment. So, it is essential to find the optimum temperature of sintering that will not lead to a decrease in HA biological properties [21].

Finally, the investment casting process is proved to be one of promise method to coat implants materials with HA. Sintering process can affect the purity and the hardness number of the HA but not the thickness of the HA coating. The pouring method to coat the mould made a thicker layer of HA coating on the material. The best sintering temperature is about $900^{\circ} \mathrm{C}$. Crystallinity that produces from this method is suitable to apply in orthopaedic implant application.

\section{CONCLUSION}

The investment casting method has successfully become one of the coating methods to coat HA coating into SS 316L surface. Pouring method produces HA layer (spongy and porous surface) with a thickness in the range of $60 \mu \mathrm{m}-110$ $\mu \mathrm{m}$. The optimum temperature of the sintering process for producing the harder coating layer of $\mathrm{HA}$ is $900^{\circ} \mathrm{C}$. The increasing temperature on the sintering process is not related with the thickness of HA coating layer. But, it is related to the purity of $\mathrm{HA}$ and the hardness of the surface. Crystallinity or $\mathrm{Ca} / \mathrm{P}$ ratio of the $\mathrm{HA}$ that produces by the casting process is 1.68 that is suitable for orthopaedic implant application.

\section{ACKNOWLEDGEMENT}

The corresponding author thanks management of Engineering Faculty, the University of Andalas for providing financial support under contract no. 027/UN.16.09.D/PL/2017, and also thanks to Ministry of Research and Education, Republic of Indonesia, for providing financial support for Program Magister Menuju Doktor Untuk Mahasiswa Unggul (PMDSU) research under contract no. 20/UN.16.17./PP.PMDSU/LPPM/2017. Thank you to an anonymous reviewer for useful advice and correction to make better quality for this paper.

\section{REFERENCES}

[1] Republika. 2013. "Indonesia Urutan Pertama Peningkatan Kecelakaan Lalu Lintas". www.republika.co.id/Berita/nasional/umum/4/11/06/nem9ncIndonesia-urutan-Pertama-peningkatan-kecelakaan-Lalu-Lintas. Accessed February 25th 2016.

[2] Merdeka. 2015. "Hingga September 2015, ada 23 Ribu kasus kecelakaan di Indonesia. http://www.merdeka.com/otomotif/hinggaSeptember-2015-ada-23-ribu-kasus-kecelakaan-di-indonesia.html. Accessed April 25th 2016.

[3] Indonesia Ministry of Health. Data dan Kondisi Penyakit Osteoporosis di Indonesia. Pusat Data dan Informasi. Jakarta Selatan. 2015.

[4] C. Oldani and A. Dominguez, Titanium as a Biomaterial for Implants, Recent Advances in Arthroplasty, Dr Samo Fokter (Ed.), ISBN: 978953-307-990-5, InTech. 2012.

[5] R.N. Patel, P.P. Gohil, "A Review on Biomaterials: Scope, Applications \& Human Anatomy Significance," International Journal of Emerging Technology and Advanced Engineering. 2012.

[6] R. Bosco, J. V. D. Beucken, S. Leeuwenburg, and J. Jansen, "Surface Engineering for Bone Implants: A Trend from Passive to Active Surfaces," Coating, vol. 2, pp: 95-119. 2012. 
[7] B. Gunawarman, M. Niinomi, T. Akahori, J. Takeda, H. Toda, "Mechanical Properties of Ti-4.5Al-3V-2Mo-2Fe and Possibility for Healthcare Applications," Materials Science and Engineering C, vol. 25, pp: 296-303. 2005.

[8] A. Ajiz, Gunawarman, J. Affi, "The Effects of Short Time Solution Treatment and Short-Time Aging on Mechanical Properties of Ti$6 \mathrm{Al}-4 \mathrm{~V}$ for Orthopaedic Applications," International Journal on Advance Science Engineering Informational Technology, vol. 5, no. 4. 2015.

[9] Gunawarman, M. Niinomi, D. Eylon, S. Fujishiro, C. Ouchi, "Effect of $\beta$ Phase Stability at Room Temperature on Mechanical Properties in $\beta$-Rich $\alpha+\beta$ Type Ti-4.5Al-3V-2Mo-2Fe Alloy," ISIJ International, vol. 42, pp: 191-199. 2002.

[10] S. Suresh, M. A. Jamil, S. Sulaiman, M. R. M. Shokor, "Optimization of Electrode Material for EDM Die-sinking of Titanium Alloy Grade 5 - Ti6Al4V," International Journal on Advance Science Engineering Informational Technology, vol. 6, no. 4. 2016.

[11] D. Williams, An Introduction to Medical and Dental Materials. Concise Encyclopedia of Medical \& Dental Materials. Pergamon Press and The MIT Press. 1990.

[12] M. H. Fathi, M. Meratian, H. Minouei, "Surface Bioactivation of Cobalt-base Alloy during Investment Casting Process," Shiraz Univ Dent J, vol. 11 (2), pp: 109-116. 2010.

[13] H. Aoki, Science and Medical Applications of Hydroxyapatite. Tokyo: JAAS. 1991.

[14] M. Svehla, P. Morberg, W. Bruce, B. Zicat, W. R. Walsh, "The Effect of Substrate Roughness and Hydroxyapatite Coating Thickness on Implant Shear Strenght,' J. Arthroplasty, vol. 17 (3), pp 304-311. 2002.

[15] M. Mhaede, A. Ahmed, M. Wollman, L. Wagner, "Evaluating The Effect of Hydroxyapatite Coating on The Corrosion Behavior of Severely Deformed 316 Ti SS for Surgical Implants," Mater Sci Eng C Mater Biol Appl, vol. 50, pp 24-30. 2015
[16] R. Z. LeGeroz and J. P. LeGeroz, Hydroxyapatite Chapter 16, (ed. T. Kokubo), vol. 1, pp 367-394, Cambridge England, Woodhead Publishing Limited and CRC Press LLC. 2008.

[17] D. Shi, Introduction to Biomaterials, (ed. D. Shi), China and Singapore, Tsinghua University Press and World Scientific Publishing Co. Pte. Ltd. 2006.

[18] D. Juliadmi, V. R. Fauzi, Gunawarman, H. Nur, M. H. Idris, "Hydroxyapatite Coating on Titanium Alloy Ti-6Al-4V with Electrophoretic Deposition (EPD) for Dental Root Application," International Journal on Advanced Science, Engineering, and Informational Technology, vol. 7, no. 6. 2017.

[19] A. Arafat, M. H. Idris, M. R. Abdul Kadir, and H. Jafari, "Characterisation of Calcium Phosphate Coating on Investment Cast 316L Stainless Steel," Material Research Innovations, vol. 14 SUPPL 12. 2014.

[20] J. M. Almanza, J. C. Escobedo, J. C. Ortiz, D. A. Ortiz, "Bioactivation of a Cobalt Alloy by Coating with Wollastonite during Investment Casting," Journal of Biomedical Research Part A. DOI: 10.1002/jbm.a.30727. 2006.

[21] J. C. Escobedo, J. C. Ortiz, J. M. Almanza, D. A. Cortes, "Hydroxyapatite Coating on a Cobalt Base Alloy by Investment Casting," Scripta Materialia, 54 pp. 1611-1615. 2006.

[22] B. Parimal, Coating Implants. Omtech. Orchid Orthopedics Solution. 2014.

[23] H. Minouei, M. Meratian, M. H. Fathi, H. Ghazvinizadeh, "Biphasic calcium phosphate coating on cobalt-base surgical alloy during investment casting," J Mater Sci: Mater Med, vol. 22, pp: 2449-2455. 2011.

[24] J. W. Boretos, M. Eden, Contemporary Biomaterials, Material and Host Response, Clinical Applications, New Technology and Legal Aspects, Noyes Publications, NJ. 1984.

[25] M. Saini, Y, Singh, "Implant Biomaterials : A Comprehensive Review," World Journal of Clinical Cases. 2014. 